\title{
The Increasing in the Floristic Diversity of the Abandoned Arrhenatherion Elatioris Meadows by Dicotyledonous Species Oversowing
}

\author{
Maria Janicka ${ }^{1 *}$, Bogumiła Pawluśkiewicz² \\ 1 Department of Agronomy, Faculty of Agriculture and Biology, Warsaw University of Life Sciences - SGGW, \\ ul. Nowoursynowska 159, 02-776 Warsaw, Poland \\ 2 Department of Environmental Improvement, Faculty of Civil and Environmental Engineering, Warsaw \\ University of Life Sciences - SGGW, ul. Nowoursynowska 159, 02-776 Warsaw, Poland \\ * Corresponding author's e-mail: maria_janicka@sggw.pl
}

\section{ABSTRACT}

The paper presents the research on the increasing in the floristic diversity of abandoned Arrhenatherion elatioris meadows through the introduction of three dicotyledonous species: Achillea millefolium, Daucus carota and Leucanthemum vulgare and the re-management. They were carried out in the meadows of the landscape reserve "The Ursynów Escarpment" ("Skarpa Ursynowska") in 2016-2018. The studies were aimed at restoring natural values of these meadows, especially their landscape and aesthetic functions. The experiment was designed in the community of Arrhenatherum elatius + Bromus inermis, as a randomised complete block, with eight replications, on the plots of $2 \mathrm{~m}^{2}$. In each plot the diaspores (collected in The Lower Pilica Valley) were sown close to the centre of the plot, within an area of $0.5 \times 0.5 \mathrm{~m}$. In the sowing year two top-cuttings and one productive one were made. In the following years the meadows were mowed once or twice. The following features were estimated: the abundance of sown species populations, the seedling density, the heights of the sown species, the height of the resident vegetation, the total ground cover, the species composition of the sward and the species richness. The improvement of the landscape and aesthetic functions of the reserve due to increasing in the species richness from 10 to 38 species and significant decreasing in Urtica dioica share was achieved. The species diversity, described with the Shannon-Wiener index, enlarged of 53\% in the first year after oversowing. The introduced species decided also about the improvement of the total ground cover. Fast and lasting effect was obtained especially on the area over-sown with $L$. vulgare. The good effects in the first two years were obtained also in the plots with $D$. carota (biennial species). A. millefolium was characterised by significantly fewer number of seedlings but its population abundance was increasing gradually during the following years. The impact of high grasses (A. elatius, B. inermis) on the soil coverage by the plants of sown species and their heights was shown. The studies also proved that in the conditions of summer drought the resident vegetation may protect the seedlings against the temperature and evapotranspiration.
\end{abstract}

Keywords: meadow restoration, species introduction, oversowing, tall herbs, Arrhenatherion elatioris, habitat code 6510, central Poland

\section{INTRODUCTION}

The abandonment of the extensive managing of permanent meadows and pastures is one of the most important threats to permanent grasslands in Europe. That problem concerns more than 20 European countries, including Poland [Warda and Kozłowski 2012, Dengler and Tischew 2018, Török et al. 2018]. Because of that many meadow and pasture habitats and their plant species are currently highly endangered [Wesche et al. 2012, Habel et al. 2013]. The example of such habitat are species-rich, extensively used, lowland, semi-natural $\mathrm{Ar}$ rhenatherion elatioris meadows (code 6510 in the NATURA 2000 network). These meadows 
are classified in the EU Habitat Directive [EEC 1992] as "lowland hay meadows". In central Poland they are vulnerable (VU) components of vegetation [Kucharski 2014].

The potential habitats of the Arrhenatherion meadows occur in almost all the country, except the higher localisations in the mountains. But the typically fully developed are located mainly in the middle and middle-eastern Poland, due to the extensive managing in the small-scale farming. These meadows are located out of the river flood-ranges, at the outskirts of the valleys, on mineral and organic soils, without the traces of bogging. They occur on the eutrophic and mesotrophic - the fresh ones (i.e. not so wet and not so dry) - locations. Thanks to colourfully blooming plant species, they belong to the most spectacular and decorative elements of the landscape. The communities of Arrhenatherion elatioris (=Arrhenatheretum medioeuropaeum) include approximately 150 species of vascular plants [Kucharski 2014]. Abandoned, due to the natural secondary succession, they lose their aesthetic and recreational values and disappear from the landscape [Kucharski 2015, Barabasz-Krasny 2016]. The other reason of the floristic impoverishment of those communities is the intensification of the grassland management (intensive fertilisation, early and frequent mowing, high stocking density and frequent grazing as well as the reseeding) [Dengler and Tischew 2018]. Moreover, these habitats are often ploughed and converted to arable lands. The present conservation status of those habitats (the monitoring in 2018) shows that only $20 \%$ of the sites have the appropriate (FV) conservation status [GIOŚ 2019].

After Poland's accession to the EU many activities supporting the protection of biological and landscape diversity of rural areas, including the ones allowing the restoration of the proper status of the natural habitats, are being taken [Klimkowska et al. 2010, Barańska 2014, Makles et al. 2014. The previous studies shown that the role of the soil seeds bank in the ecological restoration of semi-natural $\mathrm{Ar}$ rhenatherion elatioris meadows is rather small because of the lack of seeds able to germinate and limited possibilities of the diaspores spreading due to significant fragmentation of the habitats. Besides, most meadow species do not form a long-term persistent seed bank [Dölle and Schmidt 2009]. It was supported by the results of the own studies, where the diaspores of the annual dicotyledonous species consisted more than $80 \%$ of total soil seed bank [Janicka 2016]. Therefore, the restoration of high floristic diversity of the Arrhenatherion meadows demands introduction of the target species diaspores. In recent years the various methods of their harvesting and transfer are developed [Scotton et al. 2012, Haslgrübler et al. 2014, Golińska et al. 2017].

Various methods, including oversowing, are being used for the increasing in the floristic diversity of meadow communities [Kiehl et al. 2010, Török et al. 2011, Kirkham et al. 2013]. That method takes place in existing meadows with the sufficient open patches. The diaspores of wild flower species from various botanical families are mechanical spread loosely on the surface and rolled. In more than the half of the projects concerning the restoration of the floristically poor grasslands, the oversowing method was used [Hedberg and Kotowski 2010]. The popularity of that method is due to the ease of its performing. The results of the studies carried out in some European countries showed that on average $75 \%$ of the sown species reached the initial stage of development. But other studies show the relatively poor survivability of the young plants [Wallin et al. 2009]. In the own studies the species of moderately wet and dry meadows shown higher introduction efficiency in the comparison to the ones of wet grasslands [Pawluśkiewicz et al. 2019]. The effectiveness of the oversowing depends - in the large scale on the weather conditions, proper species choice and the renovation date. The seedlings and young plants development is strongly limited by the competition of the resident vegetation and the lack of proper open patches (safe sites) for the colonisation, germination and seedling survivability [Hölzel et al. 2012, Loydi 2015, Klaus et al. 2017]. The studies of Schäfer et al. [2019] showed that the high resident species richness and high land-use intensity decreased the recovery of the plant communities.

The determination of the possibilities of the increasing in the floristic diversity of abandoned Arrhenatherion elatioris meadows through the introduction of three dicotyledonous species and the re-management, in the aspect of restoring their natural values, especially the landscape and aesthetic functions, was the aim of the study. 


\section{MATERIALS AND METHODS}

\section{The study area}

The studies were carried out in the area of the landscape reserve "Ursynów Escarpment" ("Skarpa Ursynowska") - one of 12 nature reserves located in the area of the city of Warsaw. It was established in 1996 for the purpose of the protection of the fragment of high Vistula Escarpment $\left(5-18 \mathrm{~m}, 24-60^{\circ}\right)$ altogether with the meadows and the peat bogs of high natural values. The area of the reserve is equal to 20.80 ha and the buffer zone covers 134.6 ha [GDOS 2019]. Before the establishing of the reserve the meadows were used for the production purposes, since the 90. of XX century the use became highly limited, since 1998 the meadows have not been mowed.

\section{The studies in the years 2013-2015}

The studies carried out in the years 2013-2015 showed the escalated organic soil mineralisation, the simplification of the species composition (the Shannon-Wiener index 0.34-0.95), the development of herbaceous communities, the invasive, segetal and ruderal plant species and the shrubs, mainly the willow ones [Janicka et al. 2016a]. Among the meadow communities the largest areas were covered by Arrhenatherum elatius + Bromus inermis. The detailed list of the species and their shares (\% in the biomass) in the place where the experiment with oversowing was established is presented in Table 1.

\section{The studies in the years 2016-2018}

The studies concerning the species introduction was started in 2016. They were concerning the introduction of three dicotyledonous species, tall herbs, formerly numerously occurring in that area, i.e. Achillea millefolium L., Daucus carota L. and Leucanthemum vulgare LAM. They belong to the species representative for the Arrhenatheretalia elatioris order [Matuszkiewicz 2012]. The diaspores (fruits and seeds) of those species were collected by hand, in the Special Habitat Protection Area - The Lower Pilica Valley - Dolina Dolnej Pilicy (PLH140016) in the third and fourth week of September 2015. The morphometric evaluation of the collected diaspores (30 of each species) were made, their length, width and thickness were measured and thousand-seed weight
Table 1. The species composition of Arrhenatherum elatius + Bromus inermis community $(\%$ in the biomass) in 2015 - before the establishing of the experiment with the species' introduction

\begin{tabular}{|l|c|}
\hline \multicolumn{1}{|c|}{ Species } & $\%$ \\
\hline Grasses & 27.1 \\
\hline Bromus inermis Leyss. & 38.1 \\
\hline $\begin{array}{l}\text { Arrhenatherum elatius (L.) P. Beauv. ex J. } \\
\text { Preslet C. PresI }\end{array}$ & 5.1 \\
\hline Phleum pratense L. & 1.3 \\
\hline Elymus repens (L.) Gould & 3.7 \\
\hline Avenula pubescens (Huds.) Dumort. & 1.4 \\
\hline Legumes & \\
\hline Lathyrus pratensis L. & 0.1 \\
\hline Sedge & \\
\hline Carex gracilis Curtis & 20.6 \\
\hline Nonlegume forbs & 1.9 \\
\hline Urtica dioica L. & 0.7 \\
\hline Galium aparine L. & \\
\hline Solidago sp. &
\end{tabular}

were evaluated (100 seeds in each of 4 replications) (Table 2). Then their germination capacity (50 seeds in each of three replications) was stated, in variable temperatures $20 / 30^{\circ} \mathrm{C}$, i. e. $20^{\circ} \mathrm{C}$ for 16 hours (darkness) and $30^{\circ} \mathrm{C}$ for 8 hours with the light (Table 3). The analyses of the germination in laboratory according to the International Rules of Seeds Evaluation [ISTA 2019] were carried out. The catastrophic drought, which took place in 2015, caused the decreasing in the diaspores' mass, the germination capacity and increasing in the share of the dead seeds [Janicka et al. 2016b] On the base of thousand-seed weight and germination capacity the seed rates of each species were stated (Table 2).

\section{The material and methods}

The experiment was designed as a randomised complete block, with eight replications, on the plots of $2 \mathrm{~m}^{2}$. The preparation of the area consisted of the low cutting and removing the mowed biomass in autumn 2015. In spring 2016, just before the oversowing, the soil surface was thoroughly moved with a rake and the dead parts of the vegetation (litter) were removed. The diaspores were sown by hand, in broadcast manner, on April $5^{\text {th }} 2016$, and pressed to the soil surface. In each plot the diaspores were sown close to the centre of the plot, within an area of $0.5 \times 0.5 \mathrm{~m}$. The seeding of 500 healthy diaspores per $0.25 \mathrm{~m}^{2}$ was arranged, according to 
Table 2. The characteristics of the introduced species

\begin{tabular}{|l|l|c|c|c|c|c|c|c|c|}
\hline \multicolumn{1}{|c|}{ Species* $^{*}$} & Family & Life-form & Diaspore & $\begin{array}{c}\text { Length } \\
{[\mathrm{mm}]}\end{array}$ & $\begin{array}{c}\text { Width } \\
{[\mathrm{mm}]}\end{array}$ & $\begin{array}{c}\text { Thickness } \\
{[\mathrm{mm}]}\end{array}$ & TSW [g] & Durability & $\begin{array}{c}\text { Type of } \\
\text { seed bank }\end{array}$ \\
\hline $\begin{array}{l}\text { Achillea } \\
\text { millefolium L. }\end{array}$ & Asteraceae & $\mathrm{H}$ & fruit & 1.89 & 0.60 & 0.29 & 0.11 & $\mathrm{P}$ & $\mathrm{T}, \mathrm{LP}$ \\
\hline Daucus carota L. & Apiaceae & $\mathrm{H}$ & fruit & 2.29 & 1.54 & 0.78 & 1.33 & $\mathrm{~B}$ & $\mathrm{SP}$ \\
\hline $\begin{array}{l}\text { Leucanthemum } \\
\text { vulgare LAM. }\end{array}$ & Asteraceae & $\mathrm{H}$ & fruit & 1.74 & 0.65 & 0.57 & 0.40 & $\mathrm{P}$ & $\mathrm{SP}, \mathrm{LP}$ \\
\hline
\end{tabular}

Note: ${ }^{*}$ nomenclature of species according to Mirek et al. [2002]; Life form using the Raunkiaer scale, according to Ellenberg \& Leuschner [2010]: H - hemicryptophyte; Diaspore - according to Cappers, Bekker \& Jans [2006]; Length, width, thickness and TSW - thousand-seed weight - own results; Durability: P - perennial, B - biennial plant; Type of seed bank accordinig to Thompson et al. [1997]: $\mathrm{LP}=$ long-term persistent, $\mathrm{SP}=$ short-term persistent, $\mathrm{T}=$ transient.

Table 3. The analysis of the germination capacity of introduced species' seeds (\%) and the seed rate (g)

\begin{tabular}{|c|c|c|c|c|c|}
\hline \multirow[b]{2}{*}{ Species } & \multirow{2}{*}{$\begin{array}{l}\text { Germination } \\
\text { capacity }\end{array}$} & \multicolumn{3}{|c|}{ Other categories of germination analysis } & \multirow[b]{2}{*}{$\begin{array}{c}\text { Seed rate per } \\
1 \mathrm{~m}^{2} \text { [no.] }\end{array}$} \\
\hline & & $\begin{array}{l}\text { abnormal } \\
\text { seedlings }\end{array}$ & dead seeds & $\begin{array}{l}\text { fresh ungerminated } \\
\text { seeds }\end{array}$ & \\
\hline Achillea millefolium $\mathrm{L}$. & 59 & 12 & 29 & 0 & 2909 \\
\hline Daucus carota L. & 74 & 1 & 21 & 4 & 2526 \\
\hline Leucanthemum vulgare LAM. & 76 & 12 & 12 & 0 & 2450 \\
\hline
\end{tabular}

the recommendation [Scoton 2012]. After taking into consideration the actual germination capacity the seed rate was in the range of 2500-2900 diaspores per $1 \mathrm{~m}^{2}$ (Table 3). The over-seeded areas were marked permanently. In the following years nor the fertilisation nor any herbicides were applied. In 2016 two top-cuttings were made (16 May and 28 June), on the height of $10-12 \mathrm{~cm}$, and one productive cut (5 September) on the height of $6 \mathrm{~cm}$. In 2017 the experimental plots was mowed once (12 July) and in 2018 - twice (09 July and 05 October) All the plots were mowed in the same dates.

In the years 2016-2018 the development of the plants were monitored on the established plots. The following features were estimated:

- the abundance of sown species populations (expressed by level of ground cover with plants of the sown species) was estimated in 6 dates (the same that for the total coverage and after the cut in September 2016). It was determined on points scale $0-5^{\circ}$, on the basis of their occurrence in the sward: 0 - lack of plants, 1 - single $(<5 \%), 2$ - group (6-15\%), 3 - pretty numerous (16-25\%), 4 - numerous $(26-50 \%)$, and 5 - very numerous ( $>50 \%)$;

- the seedling density - the number of seedlings of the sown species in the initial period of development (78 days after sowing) and their development phase (the number of the unfolded leaves). The number of the seedlings was given per $1 \mathrm{~m}^{2}$;
- the heights of the sown species in 8 dates, in three points on the diagonal of each stated stable surface; in the sowing year measured from the base of the shoot to the last unfolded leaf, while in the following years in summer time the height of generative shoots were measured

- the height of the re-grown resident vegetation (main biomass) on the same dates and in the same way as the heights of the sown species was measured;

- the total ground cover (the coverage of the soil surface with the vegetation) was estimated in 5 dates (i.e in spring - third or fourth week of April or the beginning of May - and in summer - in the mid-July), in 5 -point scale, accepted for the grasslands and plant breeding studies: 1- bad, irregular coverage, less than $20 \%$ of soil surface coverage; 2 - poor coverage of medium regularity, $20-40 \%$ of soil coverage; 3 - medium coverage, $40-60 \% ; 4$ - good, regular coverage, $60-80 \% ; 5$-very good coverage, the dense sward, regular, $80-100 \%$;

- the species composition of the sward determined on the basis of the vegetation samples taken from the areas $\left(0.25 \mathrm{~m}^{2}\right)$ before cutting. In the paper the share of the sown species in the plant biomass of the first re-growth was given;

- the species richness - the number of the species occurred in the designated surfaces, in the dates of cuts. The Shannon-Wiener's floristic diversity index was calculated. 
The data were analysed statistically. The statistical analyse of the investigated features was made in the of randomised complete blocks pattern by means of the variance analysis (ANOVA) in the Statgraph PRO software. The verification of the difference significance was based on the Tuckey test with the significance level $\alpha=0.05$. In the tables the objective averages included to one group were marked with the same letters. The correlations between the height of the resident vegetation and the plant height of the sown species; the open patches and the number of seedlings; the soil coverage with the sown species and the total soil coverage with the vegetation were also analysed, in the paper the rectilinear correlation coefficients (r) were presented.

\section{The weather conditions}

\section{and the groundwater table}

The weather conditions in the vegetation periods 2016-2018 were highly differentiated - from exceptionally unfavourable, determined as very dry in the year 2016 and 2018, to wet in 2017 (Table 4). In the vegetation season 2016 the distribution of the rainfalls was very unfavourable. Except wet July, with 0,185 millimetres of the precipitation per $1^{\circ} \mathrm{C}$, other months of the vegetation season were very dry, and May and September - extremely dry. The year 2017 was the most favourable for the growth and development of the meadow vegetation. During the growing season of this year there was about $0.194 \mathrm{~mm}$ of precipitation at $1{ }^{\circ} \mathrm{C}$. The vegetation season of 2018 was exceptionally hot and characterised itself with the sum of precipitation significantly lower than the long-term average. High air temperatures with intensive insolation and low precipitation have already caused in the second half of April the development of the agricultural drought. The drought lasting from April negatively impacted the development of the meadow plants.

The water table in the vegetation season was usually between 60 and 90 centimetres (Table 4), but during the catastrophic drought in August 2016 decreased to 120 centimetres. However in 2017, because of high precipitations, the water table increased to 30 centimetres (in the beginning of May, in the end of June and in the middle of September). In the vegetation period of 2017, the groundwater table was more than 33 centimetres higher at average in the comparison with the previous year. Remaining precipitation deficiency in 2018 impacted the significant lowering of the water table, but it was still higher in the comparison with 2016.

\section{The soil conditions}

The experiment was situated on the mineralorganic soil. The content of organic matter was

Table 4. The weather conditions in growing seasons 2016-2018, water table and climatic rainfall coefficient $\left(\Sigma \mathrm{mm} \Sigma^{\circ} \mathrm{C}^{-1}\right)$. Meteorological Station at Ursynów (WULS - SGGW, Warsaw)

\begin{tabular}{|c|c|c|c|c|c|c|c|}
\hline \multirow{2}{*}{ Year } & \multicolumn{6}{|c|}{ Month } & \multirow{2}{*}{$\begin{array}{c}\text { Growing season } \\
\text { IV-IX } \\
\end{array}$} \\
\hline & IV & V & VI & VII & VIII & IX & \\
\hline \multicolumn{8}{|c|}{ Mean temperature $\left({ }^{\circ} \mathrm{C}\right)$} \\
\hline 2016 & 10.0 & 16.3 & 19.8 & 20.3 & 19.3 & 16.5 & 17.1 \\
\hline 2017 & 8.0 & 14.9 & 18.9 & 19.2 & 20.0 & 14.1 & 15.9 \\
\hline 2018 & 14.0 & 18.2 & 19.8 & 21.5 & 21.4 & 16.5 & 18.6 \\
\hline \multicolumn{8}{|c|}{ Sum of precipitation (mm) } \\
\hline 2016 & 34.2 & 23.3 & 56.9 & 116.5 & 71.7 & 9.8 & 312.4 \\
\hline 2017 & 62.1 & 68.3 & 106.2 & 111.0 & 68.5 & 146.8 & 562.9 \\
\hline 2018 & 19.3 & 54.9 & 34.8 & 82.0 & 87.5 & 68.0 & 346.5 \\
\hline \multicolumn{8}{|c|}{ Water table $(\mathrm{cm})$} \\
\hline 2016 & 69.5 & 88.5 & 97.9 & 87.2 & 87.2 & 117.0 & 91.3 \\
\hline 2017 & 65.5 & 43.5 & 74.5 & 52.6 & 59.7 & 44.2 & 58.0 \\
\hline 2018 & 58.7 & 70.8 & 76.3 & 76.7 & 84.5 & no data & $73.4^{*}$ \\
\hline \multicolumn{4}{|c|}{ Characteristics of growing seasons } & \multicolumn{4}{|c|}{ Hydrothermal index of Vinczeffy $\left(\sum \mathrm{mm} \cdot \sum^{\circ} \mathrm{C}^{-1}\right)$} \\
\hline 2016 & \multicolumn{3}{|c|}{ very dry } & \multicolumn{4}{|c|}{0.100} \\
\hline 2017 & \multicolumn{3}{|c|}{ wet } & \multicolumn{4}{|c|}{0.194} \\
\hline 2018 & \multicolumn{3}{|c|}{ very dry } & \multicolumn{4}{|c|}{0.102} \\
\hline $1981-2010$ & \multicolumn{3}{|c|}{ dry } & \multicolumn{4}{|c|}{0.124} \\
\hline
\end{tabular}

Note: * mean calculated without IX. 
equal to $207.2 \mathrm{~g} \mathrm{C}_{\text {org }} \cdot \mathrm{kg}^{-1}$. The estimation of the soil $\mathrm{pH}$ and the contents of selected macronutrients in the root zone showed very high phosphorus content (546.0 $\mathrm{mg} \mathrm{P} \cdot \mathrm{kg}^{-1}$ of soil DM), very low potassium content $\left(108.9 \mathrm{mg} \mathrm{K} \cdot \mathrm{kg}^{-1} \mathrm{DM}\right)$ and the slightly acid soil $\left(\mathrm{pH}_{1 \mathrm{~mol} \cdot \mathrm{L}}^{-1} \mathrm{KCl}=5.6\right)$.

\section{RESULTS AND DISCUSSION}

\section{The abundance of sown species population}

The abundance of sown species populations was determined on the basis of their occurrence in the sward (soil coverage), in points scale $0-5^{\circ}$. In April 2016 the seedlings of the sown species appeared (24 days after sowing). During that period the coverage of the soil surface was not significantly differentiated depending on the species (Table 5). Such differences occurred from July 2016. D. carota and $L$. vulgare quickly and pretty numerous covered the soil. The population of $D$. carota developed strongly and was very numerous in 2016, and L. vulgare - in 2017 (more than 60\% in average). $L$. vulgare covered the surface of the soil at the best, especially in springtime (AprilMay), because it is the early species, whereas in summertime (July) and in autumn (September) 2016 D. carota was characterised by the better coverage (late species). Statistically the differences in the level of coverage between those species were not significant, except the measurements in 2018 , when D. carota disappeared (biennial species). That species enlarged its range gradually and in the first period after sowing (April-July) it significantly worse covered the soil in the comparison with others species, and in the end of the vegetation season - significantly worse than $D$. carota. The sufficient, satisfactory soil coverage by $A$. millefolium was not obtained until spring 2017. The abundance of that species' population was then similar to the D. carota one, and in the last year of the studies (2018) - to L. vulgare one. Similar abundance of the A. millefolium population was stated after the seeds' introduction during the studies on the flood meadows' restitution. Then it was proved that the removing of the sward and mechanical soil cultivation created the best conditions for that species' development [Pawluśkiewicz et al. 2019]. Irrespective of species the level of soil coverage by sown species was negatively correlated with the ground cover by resident vegetation $\left(\mathrm{r}=-0.719^{* *}\right)$.

\section{The seedling density}

After 2.5 months from the oversowing, the seedling recruitment of the sown species was much differentiated (Table 6). The seedlings of $L$. vulgare were most numerous. Those seedlings, as well as the $D$. carota ones, were significantly more numerous than the A. millefolium ones. The plants of $A$. millefolium were much less developed (3-4 leaves unfolded), when the number of the leaves on other species was even doubled. It was probably related to the A. millefolium diaspores' size. They were the smallest of the diaspores of other sown species (Table 2). According to i.a. Lönnberg and Eriksson [2013], the large-seeded species, which contain more stored resources, grow faster and produce stronger seedlings. Moreover the seedlings germinating from large seeds generally cope better with environmental stresses such as shading, competition and thick litter layers, than the seedlings germinating from small seeds.

The weather conditions highly affected the initial development of the sown species. The Vinczeffy hydrothermal index characterises that period (77 days from the sowing) as extremely dry (0.086). The precipitation deficiency affected the strong drying of the top soil layer. In those conditions the plants of resident species mitigated the moisture stress and the higher number of $L$. vulgare and D. carota seedlings developed and remained on the surfaces with lower amount of open patches (gaps) in the sward. The negative values of the correlation coefficient $\mathrm{r}=-0.585^{* *}$ and $\mathrm{r}=-0.470^{* *}$, for $L$. vulgare and D. carota respectively, indicate this relationship. In the plots

Table 5. The abundance of sown species populations (scale $0-5^{\circ}$ )

\begin{tabular}{|c|c|c|c|c|c|c|c|}
\hline \multirow{2}{*}{ Species } & \multicolumn{6}{|c|}{ Date of assessment } & \multirow{2}{*}{ mean } \\
\hline & 04.2016 & 07.2016 & 09.2016 & 05.2017 & 07.2017 & 04.2018 & \\
\hline Achillea millefolium L. & $0.7^{\mathrm{aA}}$ & $1.5^{\mathrm{aAB}}$ & $2.1^{\mathrm{aBC}}$ & $3.1^{\mathrm{ac}}$ & $3.2^{\mathrm{ac}}$ & $2.7^{\mathrm{bc}}$ & $2.2^{\mathrm{a}}$ \\
\hline Daucus carota L. & $1.0^{\mathrm{aA}}$ & $3.9^{\mathrm{bB}}$ & $4.2^{\mathrm{bB}}$ & $3.5^{\mathrm{abB}}$ & $3.4^{\mathrm{abB}}$ & $0.7^{\mathrm{aA}}$ & $2.8^{a b}$ \\
\hline $\begin{array}{l}\text { Leucanthemum } \\
\text { vulgare LAM. }\end{array}$ & $1.1^{\mathrm{aA}}$ & $3.6^{\mathrm{bB}}$ & $3.0^{\mathrm{abB}}$ & $4.6^{\mathrm{bB}}$ & $4.4^{\mathrm{bB}}$ & $3.2^{\mathrm{bB}}$ & $3.3^{b}$ \\
\hline
\end{tabular}

Note: ${ }^{\mathrm{a}-\mathrm{c}}$ homogenous groups for the columns, ${ }^{\mathrm{A}-\mathrm{C}}$ homogenous groups in the lines. 
with $A$. millefolium very few seedlings germinated and that relationship was not found.

\section{The heights of the sown species}

The plants of $D$. carota were growing fastest in the initial period of the sown species' growth and development (till July 2016) (Table 7). Their heights were then significantly greater in the comparison with L. vulgare and A. millefolium, but in September 2016 - only with L. vulgare. In the first year after sowing (in subsequent dates of measurements in 2017) the growth of $D$. carota and A. millefolium shoots was similar. The L. vulgare characterised itself with different growth strategy, what is the consequence of other individual' development strategy of that species (the early one, with medium-height generative shoots). In springtime the L. vulgare shoots were significantly higher, but in summertime - significantly lower than other introduced species'. In the next year (2018), after D. carota disappeared, A. millefolium was the species of the significantly highest plants. The measurements of the plants' height showed their significant differentiation depending on the year e.g. the $A$. millefolium plants were - in average - more than $14 \mathrm{~cm}$ higher than in 2018. Irrespectively to the species the highest heights were noted in 2017. Faster plant growth

Table 6. The mean number of the sown species' seedlings $\left(\right.$ no. $\left.\cdot \mathrm{m}^{-2}\right)$ in the early development phase (77 days after sowing) and their development phase (the number of unfolded leaves)

\begin{tabular}{|l|c|c|}
\hline \multicolumn{1}{|c|}{ Species } & $\begin{array}{c}\text { Number of } \\
\text { seedlings } \\
\left(\mathrm{no} \cdot \mathrm{m}^{-2}\right)\end{array}$ & $\begin{array}{c}\text { Development phase } \\
\text { (number of leaves) }\end{array}$ \\
\hline $\begin{array}{l}\text { Achillea } \\
\text { millefolium L. }\end{array}$ & $16^{\mathrm{a}}$ & $3-4$ \\
\hline Daucus carota L. & $92^{\mathrm{b}}$ & from 2-3 to $4-6$ \\
\hline $\begin{array}{l}\text { Leucanthemum } \\
\text { vulgare LAM. }\end{array}$ & $124^{\mathrm{b}}$ & from 3 to $5-6$ \\
\hline
\end{tabular}

this year was the result of more favorable weather conditions, especially the soil moisture. Additionally, the plant heights of the sown species were positively correlated with the heights of resident species $(r=0.892 * *)$, what was the effect of the light competition.

\section{The height of the resident vegetation (main biomass)}

Two species of high grasses - Arrhenatherum elatius and Bromus inermis dominated in the resident vegetation. In the following years these species increased their share and Urtica dioica - decreased. In all the measurements dates the height of the resident vegetation was similar on all the plots with sown species (Table 8). The height of the plants before the mowing in July 2017 was the exception. During that period they were significantly higher on the plots with $D$. carota and A. millefolium than on the ones with L. vulgare, what was the effect of greater share of the dominant species in the sward. On the plots with $D$. carota and A. millefolium the plants of $A$. elatius developed exceptionally high shoots $(110.3 \mathrm{~cm}$ and $105 \mathrm{~cm}$ tall, respectively). They were about $10 \mathrm{~cm}$ higher than on plots with L. vulgare. B. inermis, on the other hand, produced the highest shoots on plots with $A$. millefolium (on average $99.5 \mathrm{~cm}$ ). They were about $7 \mathrm{~cm}$ higher than on plots with $L$. vulgare and D. carota. In the years with lack of precipitation $(2016,2018)$ the differences in shoot heights of both dominant species (A. elatius and B. inermis) were lower.

\section{The total ground cover}

The significant differentiation of the plots' coverage depending on the sown species was stated only in 2017 (Table 9). Significantly higher, quite good and regular cover was typical for the plots with L. vulgare in comparison with $D$. carota.

Table 7. The plant heights of the sown species in the subsequent measure dates in the vegetation periods 2016-2018

\begin{tabular}{|c|c|c|c|c|c|c|c|c|c|}
\hline \multirow{2}{*}{ Species } & \multicolumn{8}{|c|}{ Date of measurement } & \multirow{2}{*}{ Mean* } \\
\hline & 06.2016 & 07.2016 & 09.2016 & 05.2017 & 07.2017 & 09.2017 & 04.2018 & 07.2018 & \\
\hline Achillea millefolium L. & $2.0^{\mathrm{a}}$ & $13.8^{a}$ & $26.2^{\mathrm{ab}}$ & $16.4^{a}$ & $81.2^{b}$ & $42.5^{b}$ & $17.3^{b}$ & $66.9^{b}$ & $28.5^{b}$ \\
\hline Daucus carota L. & $7.2^{b}$ & $22.4^{b}$ & $27.8^{b}$ & $15.6^{a}$ & $86.0^{b}$ & $43.0^{b}$ & $11.9^{a}$ & - & $30.6^{b}$ \\
\hline $\begin{array}{l}\text { Leucanthemum } \\
\text { vulgare LAM. }\end{array}$ & $3.2^{\mathrm{a}}$ & $12.9^{a}$ & $20.3^{a}$ & $20.4^{b}$ & $55.4^{\mathrm{a}}$ & $15.3^{a}$ & $9.6^{a}$ & $49.6^{a}$ & $19.6^{a}$ \\
\hline Mean & $4.1^{\mathrm{A}}$ & $16.4^{\mathrm{B}}$ & $24.8^{c}$ & $17.5^{\mathrm{B}}$ & $74.2^{\mathrm{E}}$ & $33.6^{\mathrm{D}}$ & $12.9^{\mathrm{B}}$ & - & - \\
\hline
\end{tabular}

Note:* without 07.2018; ${ }^{\mathrm{a}-\mathrm{b}}$ homogenous groups for the columns, ${ }^{\mathrm{A}-\mathrm{E}}$ homogenous groups in the line. 
Table 8. The heights of the resident vegetation (main mass) in the following dates of the vegetation season, 2016-2018

\begin{tabular}{|c|c|c|c|c|c|c|c|c|}
\hline \multirow{2}{*}{ Species } & \multicolumn{7}{|c|}{ Date of measurement } & \multirow{2}{*}{ Mean } \\
\hline & 05.2016 & 09.2016 & 05.2017 & 07.2017 & 09.2017 & 04.2018 & 07.2018 & \\
\hline Achillea millefolium L. & 24.2 & 39.8 & 27.8 & $84.9^{b}$ & 54.8 & 31.7 & 66.0 & $47.2^{\mathrm{b}}$ \\
\hline Daucus carota L. & 24.2 & 38.8 & 25.9 & $95.0^{\mathrm{b}}$ & 56.4 & 30.7 & 63.4 & $47.8^{b}$ \\
\hline $\begin{array}{l}\text { Leucanthemum } \\
\text { vulgare LAM. }\end{array}$ & 25.1 & 40.3 & 27.8 & $66.1^{\mathrm{a}}$ & 46.1 & 27.0 & 67.6 & $42.9^{a}$ \\
\hline Mean & $24.5^{\mathrm{A}}$ & $39.6^{\mathrm{B}}$ & $27.5^{\mathrm{A}}$ & $82.0^{\mathrm{E}}$ & $52.4^{\mathrm{C}}$ & $29.8^{A}$ & $65.7^{\mathrm{D}}$ & \\
\hline
\end{tabular}

Note: ${ }^{\mathrm{a}-\mathrm{b}}$ homogenous groups for the columns, ${ }^{\mathrm{A}-\mathrm{E}}$ homogenous groups in the line.

Table 9. The total cover - soil coverage altogether by resident species and sown species - in 5 dates, 5-point scale

\begin{tabular}{|c|c|c|c|c|c|c|}
\hline \multirow{2}{*}{ Species } & \multicolumn{5}{|c|}{ Date of assessment } & \multirow{2}{*}{ Mean } \\
\hline & 04.2016 & 07.2016 & 05.2017 & 07.2017 & 04.2018 & \\
\hline Achillea millefolium L. & 2.7 & 1.6 & $2.9^{\mathrm{ab}}$ & $3.2^{\mathrm{ab}}$ & 3.7 & $2.8^{\mathrm{ab}}$ \\
\hline Daucus carota L. & 2.2 & 1.9 & $2.4^{\mathrm{a}}$ & $2.7^{a}$ & 3.2 & $2.5^{\mathrm{a}}$ \\
\hline $\begin{array}{l}\text { Leucanthemum } \\
\text { vulgare LAM. }\end{array}$ & 2.4 & 1.8 & $3.9^{b}$ & $3.9^{b}$ & 3.2 & $3.0^{\mathrm{b}}$ \\
\hline Mean & $2.4^{\mathrm{B}}$ & $1.7^{\mathrm{A}}$ & $3.0^{\mathrm{BC}}$ & $3.3^{\mathrm{C}}$ & $3.3^{c}$ & \\
\hline
\end{tabular}

Note: ${ }^{\mathrm{a}-\mathrm{b}}$ homogenous groups for the columns, ${ }^{\mathrm{A}-\mathrm{C}}$ homogenous groups in the line.

Relatively poor coverage of medium regularity of the plots with $D$. carota was the result of the character of that species' development (the upright i.e. erect stem) and significant share in the sward of the tall grasses (A. elatius, B. inermis), which limited tillering of species of the low, long-lasting shadowed layers of the sward. The plots with $A$. millefolium characterised themselves by the average coverage, statistically insignificantly different in the comparison with other sown species. On the plots with $L$. vulgare the soil coverage by $L$. vulgare showed important influence on the total coverage, what was confirmed by the positive value of the correlation coefficient $\left(\mathrm{r}=0,777^{* *}\right)$. That dependency was not stated for other sown species.

The weather conditions in the respective vegetation periods also significantly influenced the total cover. In the years 2016 and 2018 the best cover were noted after vernal grasses tillering (Table 9). Considerable deficiency of precipitations in summer 2016 caused loosing of the sward and irregular coverage, as well as the increasing in the open patches, uncovered by vegetation. In 2017, with favourable moisture conditions, the plants intensively developed through all the vegetation period and in summer they were characterised by the medium coverage, similarly to springtime.

\section{The share of the sown species in the plant biomass}

In the year of sowing (2016) the largest share (\%) amongst the sown species was characteristic of $D$. carota and the smallest one was A. millefolium (Figure 1). L. vulgare was

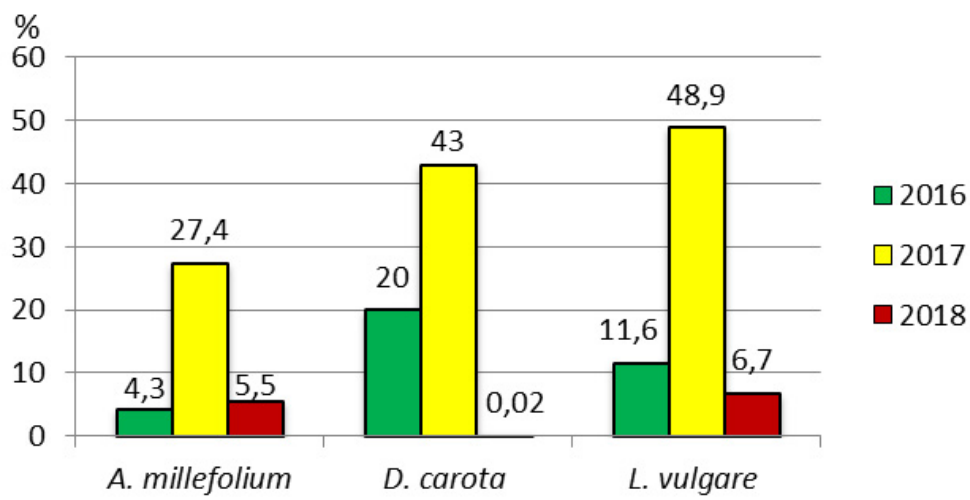

Figure 1. The share (\%) of the sown species in the plant biomass of the first re-growth in the years 2016-2018 
characterised by the medium value. In the next year all sown species strongly developed, especially A. millefolium, which share in the biomass increased six times in the comparison with the previous year (from 4.3 to $27.4 \%$ ). The share of other species was higher than $40 \%$ (Figure 1). In the third year of the studies $D$. carota disappeared (biennial species), and the other species were characterised by small coverage and share in the biomass $(5.5-6.7 \%)$. Probably it was the effect of unfavourable weather conditions (the soil drought from middle April).

\section{The species richness}

During the investigations in the designated surfaces (plot level) the increasing in the species richness was observed. In that period the species introduced by the oversowing developed, as well as the ones from the soil seeds bank and from the rain of seeds from the neighbour areas. The number of species in that plots increased from 4.5 to 9.1 on average and ranged from 4 to 14 (Table 10). In the first two years no significant differences were noted depending on the sown species. But in the last year the plots with $A$. millefolium were characterised by a significantly higher number of species in the comparison with the plots with D. carota. In the plots with $L$. vulgare the intermediate values of species number were noted through all the investigation period. At the line level the number of species ranged from 11 to 29 and was highest at the line with $A$. millefolium, just like at the plot level. All over the total area the highest number of the species
(38) was noted in 2017. That value was more than two times as high as at the beginning of the study (Table 10) and almost four times higher than in the year before the beginning of the study (Table 1). The perennial nonlegume forbs constituted the largest group (64\%) among newlydeveloped species. But from the soil seed bank mainly the arable weeds and ruderal species developed: Cirsium arvense (L.) Scop., Conyza canadensis (L.) Cronquist, Erigeron annuus (L.) Pers. (the invasive taxa), Rumex crispus (L.), Rumex acetosa L., Sonchus arvensis L., Carduus crispus L., Equisetum arvense L. Those species occurred in the close neighbourhood of the reserve or in the adjacent areas, from which the diaspores could have been moved e.g. by wind. The emergence of three Fabaceae species: Vicia cracca L., Trifolium repens L. and Medicago lupulina L. is noteworthly. These species are reported to have persistent seed bank [Thompson et al. 1997], so it is possible that they have colonized plots from seeds in the soil. The following, colourfully blooming species also improved the aesthetical function of the study area: Centaurea jacea L., Taraxacum officinale F.H. Wigg., Ranunculus repens L., Hieracium caespitosum Dumort., Galium mollugo L. and Melandrium album (Mill.) Garcke. The Shannon-Wiener's floristic diversity index increased from 0.62 to 0.95 (Figure 2), what indicates the increasing in the species richness. This index reached the highest values in 2017, the year of the most advantageous weather conditions for the meadow plants' development.

Table 10. The species richness (mean values) - the number of species which developed in the designated surfaces (in the bracket the lowest and highest values on the plot)

\begin{tabular}{|c|c|c|c|c|c|}
\hline \multirow{2}{*}{ Species } & \multicolumn{4}{|c|}{ Date of measurement } & \multirow{2}{*}{ Mean } \\
\hline & 05.2016 & 09.2016 & 07.2017 & 07.2018 & \\
\hline \multicolumn{6}{|c|}{ Plot level $\left(0.25 \mathrm{~m}^{2}\right)$} \\
\hline Achillea millefolium $\mathrm{L}$. & $4.9(3-9)$ & $7.2(5-10)$ & $9.9(7-13)$ & $9.2^{b}(8-11)$ & 7.8 \\
\hline Daucus carota L. & $4.5(2-8)$ & $6.9(5-10)$ & $8.4(5-11)$ & $6.9^{a}(5-9)$ & 6.7 \\
\hline Leucanthemum vulgare LAM. & $4.1(2-9)$ & $7.1(4-12)$ & $9.0(5-14)$ & $8.1^{\text {ab }}(5-11)$ & 7.1 \\
\hline Mean & $4.5^{\mathrm{a}}$ & $7.1^{\mathrm{b}}$ & $9.1^{\mathrm{c}}$ & $8.1^{b c}$ & \\
\hline \multicolumn{6}{|c|}{ Line level $\left(2 \mathrm{~m}^{2}\right)$} \\
\hline Achillea millefolium L. & 15 & 20 & 29 & 26 & 22.5 \\
\hline Daucus carota L. & 11 & 16 & 23 & 18 & 17 \\
\hline Leucanthemum vulgare LAM. & 12 & 17 & 26 & 24 & 19.7 \\
\hline \multicolumn{6}{|c|}{ Total area $\left(6 \mathrm{~m}^{2}\right)$} \\
\hline Number of species & 18 & 27 & 38 & 32 & 28.7 \\
\hline
\end{tabular}

Note: ${ }^{\mathrm{a}-\mathrm{c}}$ homogenous groups in the line. 


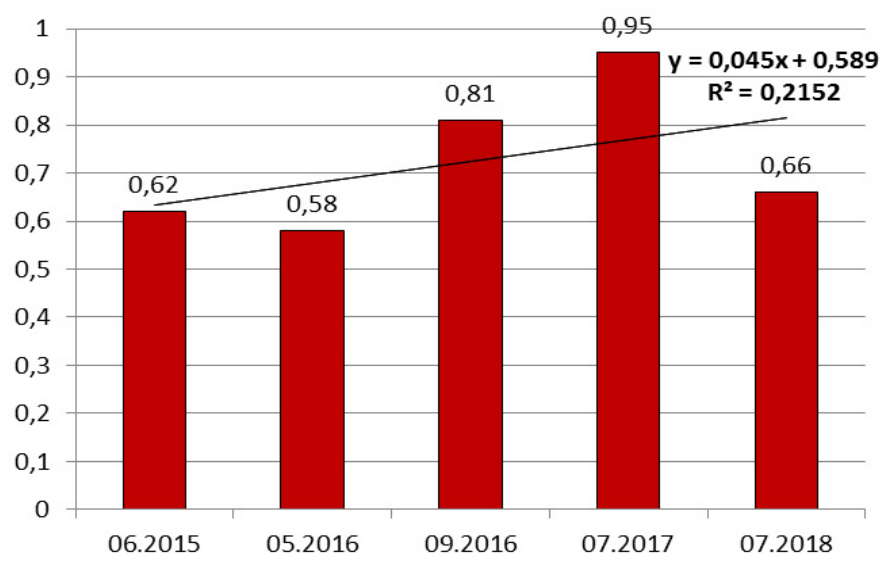

Figure 2. The floristic diversity, described by the Shannon-Wiener index, from June 2015 to July 2018

\section{CONCLUSIONS}

The oversowing is usually used on previously intensively managed meadows, with simplified, homogenous species composition, most often in North-European countries [Kiehl et al. 2010]. In Poland so far, only the single attempts of restore the floristic-rich Arrhenatherion elatioris meadows were carried out [Examples from the SALVERE project in Scotton et al. 2012]. The results of our study confirmed that the seed introduction by the oversowing method and the re-management may affect the increasing in the biological diversity of abandoned Arrhenatherion meadows. The improvement of the landscape and aesthetic functions of the reserve due to significant decreasing in $U r$ tica dioica share and increasing in the species richness from 10 to 38 species was achieved. The species diversity of the sward meadow, described with the Shannon-Wiener index, enlarged of 53\% in the first year after sowing the introduced species. The introduced species decided also about the improvement of the total ground cover. They developed on all over-seeded plots. Especially quick and lasting effect was obtained on the plots oversown with $L$. vulgare - the species of early-flowering and early seed dispersal. The importance of that characteristic for the successful introduction was emphasized by Engst et al. [2017]. The good effects in the sowing year and in the year after sowing were obtained also in the plots with $D$. carota. However, the problem was with its maintenance in the sward, because it is the biennial species and the cut was made before the seed formation. The sward with that species should be mowed only after the seed dispersion, because the oversowing made every two years may be economically unprofitable. A. millefolium was characterised by pretty numerous population abundance, increasing gradually during the following years.

Although the plant introduction in moderate wet, periodically dry habitats seems to be easier and is more effective than in the wet, flooded ones, but it is related with many problems. One of them is the slow development after sowing in the case of the fine-seeded species, typical for the majority of the meadow species. During our studies A. millefolium was characterised by significantly fewer number of seedlings than $L$. vulgare and D. carota. However, results of Lönnberg and Eriksson [2013] showed a generally positive, albeit weak, relationship between seed size and recruitment. Second important element of successive introduction is the size of the gaps in the sward [Fibich et al. 2013]. They importance is connected with better early development of the sown species. It was found that seed addition affected increasing in plant species richness, but only in connection with sward disturbance [Klaus et al. 2017]. For that reason it is necessary to low sward-cutting and removing the litter (dead vegetable biomass). It enables not only the access of the light to the germinating seeds, but also limits the impact of secondary plant metabolites (mainly polyphenols), released from the dead roots and remains of old sward, decaying in the soil. The negative impact of the mulch on A. millefolium development was proved by Pawluśkiewicz et al. [2019]. The strong competition of quickly re-growing the resident vegetation, compared to slower development of the sown species, especially in the early stage of their development, is also the serious problem. The positive impact of disruption diminishes with increasing of plant canopy height and decreasing in opening size [Kostrakiewicz-Gierałt 2014]. During conducted studies the impact of 
high grasses (A. elatius, B. inermis) on the level of soil coverage by the plants of sown species (r $\left.=-0.719^{* *}\right)$ and their heights $\left(\mathrm{r}=0.892^{* *}\right)$ was shown. Not only high grasses, but also the creeping ones spreading by numerous, short rhizomes e.g. Poa pratensis L., Festuca rubra L. and the dicotyledonous species able to re-grow even from small fragments of the rootstocks are very competitive. Such impact may be limited by the topcuttings. But the studies proved that in the conditions of summer drought the resident vegetation may protect the seedlings against the temperature and evapotranspiration. The development of species from the sown seeds was also limited by the plants developing from the soil seed bank and the rain of seeds from adjacent areas. However poorly developed seed banks of dry-mesophilous meadows do not guarantee the regeneration of speciesrich vegetation [Janicka 2016]. For this reason, mainly arable weeds and ruderal species developed during the realised studies.

The obtained results confirmed that the grasslands of low resident plant species richness compared with grasslands of high resident plant species richness showed increased recovery of plant communities [Schäfer et al. 2019] and the importance of regular management for the species-rich hay meadows. They may be the base for further studies on increasing in floristic diversity of the Arrheratherion meadows and others endangered grassland communities as well as restoration of the destroyed meadow habitats using other dicotyledonous species.

\section{Acknowledgements}

This paper was presented at The International Scientific Conference, 10th Forum of Ecological Engineering, 9-11 September 2019, Kazimierz Dolny, Poland (oral Session C4)

\section{REFERENCES}

1. Barabasz-Krasny B. 2016. Vegetation differentiation and secondary succession on abandoned agricultural large-areas in south-eastern Poland. Biodiv. Res. Conserv. 41, 35-50.

2. Barańska K. 2014. Best Practice Handbook for the conservation of xerothermic grasslands. Coordination Center for Environmental Projects. Warsaw. [In Polish].

3. Cappers R.T.J., Bekker R.M., Jans J.E.A. 2006. Digital seed atlas of the Netherlands. Groningen Archaeological Studies, Vol 4. - Barkhuis Publishing and Groningen Univ. Library.
4. Dengler J., Tischew S. 2018. Grasslands of western and northern Europe - between intensification and abandonment. In: Squires, V.R., Dengler, J., Feng, H., Hua, L. (eds.) Grasslands of the world: diversity, management and conservation. CRC Press, Boca Raton, USA, 27-63.

5. Dölle M., Schmidt W. 2009. The relationship between soil seed bank, above-ground vegetation and disturbance intensity on old-field successional permanent plots. Applied Vegetation Science, 12(4), 415-428.

6. EEC 1992. Council Directive 92/43/EEC of 21 May 1992 on the conservation of natural habitats and of wild fauna and flora (Dz. U. L 206 of July 22, 1992, as amended)

7. Ellenberg, H., Ch. Leuschner 2010. Vegetation Mitteleuropas mit den Alpen. 6. Auflage. Stuttgart: U1mer UTB [in German].

8. Engst, K., Baasch, A., Bruelheide, H. 2017. Predicting the establishment success of introduced target species in grassland restoration by functional traits. Ecology and Evolution, 7, 7442-7453.

9. Fibich P., Vitová A., Macek P., Lepš J., Cáceres M. 2013. Establishment and spatial associations of recruits in meadow gaps. J. Veg. Sci., 24(3), 496-505.

10. GDOS [General Directorate for Environmental Protection] 2019. Nature Reserve "Ursynów Escarpment - Skarpa Ursynowska". Available at http:// www.crfop.gdos.gov.pl [In Polish].

11. GIOŚ [Inspectorate of Environmental Protection] 2019. Monitoring of species and natural habitats, with particular emphasis on Natura 2000 habitat protection areas. Monitoring results in 2016-2018. Report on habitat monitoring 6510 Lowland and mountain meadows extensively used (Arrhenatherion elatioris). State Environmental Monitoring. Available at http://www.siedliska.gios.gov.pl/pl/ [In Polish].

12. Golińska B., Czerwiński M., Goliński P. 2017. Harvesting seeds of an Arrhenatherion meadow as a source of propagation material for grassland restoration. In: Grassland resources for extensive farming systems in marginal lands: major drivers and future scenarios: Proc. of the 19th Symposium of the European Grassland Federation, Alghero, Italy, Grassland Science in Europe, 22, 485-487.

13. Habel J.C., Dengler J., Janišová M., Török P., Wellstein C., Wiezik M. 2013. European grassland ecosystems: Threatened hotspots of biodiversity. Biodivers. Conserv., 22(10), 2131-2138.

14. Haslgrübler, P., Krautzer, B., Blaschka, A., Graiss, W., Pötsch, E.M. 2014. Quality and germination capacity of seed material harvested from an Arrhenatherion meadow. Grass and Forage Science 69(3), 454-461.

15. Hedberg P., Kotowski W. 2010. New nature by sowing? The current state of species introduction in grassland restoration, and the road ahead. Journal for Nature Conservation, 18(4), 304-308. 
16. Hölzel N., Buisson E., Dutoiti T. 2012. Species introduction - a major topic in vegetation restoration. Applied Vegetation Science, 15(2), 161-165.

17. International Seed Testing Association [ISTA] 2019. International Rules for Seed Testing. https://www.ingentaconnect.com/content/ista/ rules/2019/00002019/00000001.

18. Janicka, M. 2016. The evaluation of soil seed bank in two Arrhenatherion meadow habitats in central Poland. Acta Sci. Pol. Agricultura, 15(4), 25-38.

19. Janicka M., Pawluśkiewicz B., Dąbrowski P. 2016a. Natural and usefulness valorisation of the meadow communities with the share of Arrhenatherum elatius and Bromus inermis formed as the result of managing abandonment in the "Skarpa Ursynowska" nature reserve. Polish Journal of Agronomy, 27, 71-80. [In Polish].

20. Janicka M., Pawluśkiewicz B., Małuszyńska E., Szydłowska A. 2016b. The estimation of some wild flowers seed material from the natural-valuable meadow habitats. Annals of Warsaw University of Life Sciences-SGGW - Land Reclamation, 48(4), 329-340.

21. Kiehl, K., Kirmer, A., Donath, T. W., Rasran, L., Hölzel, N. 2010. Species introduction in restoration projects-Evaluation of different techniques for the establishment of semi-natural grasslands in Central and Northwestern Europe. Basic and Applied Ecology, 11, 285-299.

22. Kirkham F.W., Bhogal A., Chambers B.J., Dunn R.M., Tallowin J.R.B. 2013. Effects of spreading species-rich green hay on the botanical composition of an agriculturally improved hay meadow in northern England. Grass and Forage Science, 68(2), 260-270.

23. Klaus V.H., Schäfer D., Kleinebecker T., Fischer M., Prati D., Hölzel N. 2017. Enriching plant diversity in grasslands by large-scale experimental sward disturbance and seed addition along gradients of land-use intensity. Journal of Plant Ecology 10(4), 581-591.

24. Klimkowska A., Kotowski W., van Diggelen R., Grootjans A.P., Dzierża P., Brzezińska K. 2010. Vegetation re-development after fen meadow restoration by topsoil removal and hay transfer. Restor. Ecol. 18(6), 924-933.

25. Kostrakiewicz-Gierałt K. 2014. The effect of neighbouring plant height, disturbance level and gap size on spontaneous recruitment of large-seeded and small-seeded species in Molinietum caeruleae meadows. Polish Journal of Ecology, 62(2), 289-306. https://doi.org/10.3161/104.062.0209

26. Kucharski L. 2014. Vegetation of oat-grass meadows in central Poland. Steciana, 18(3), 119-125.

27. Kucharski L. 2015. Vegetation in abandoned meadows in central Poland: Pilsia Valley. Case study. Acta Sci. Pol. Agricultura, 14(2), 37-47.

28. Lönnberg K., Eriksson O. 2013. Relationships between intra-specific variation in seed size and recruitment in four species in two contrasting habitats. Plant Biology 15(3), 601-606.
29. Loydi A., Donath T.W., Otte A., Eckstein R.L. 2015. Negative and positive interactions among plants: effect of competitors and litter on seedling emergence and growth of forest and grassland species. Plant Biology 17(3), 667-675.

30. Makles M., Pawlaczyk P., Stańko R. 2014. Best Practice Handbook for the conservation of wetlands. Coordination Center for Environmental Projects. Warsaw. [In Polish].

31. Matuszkiewicz, W. 2012. Guide for the determination of plant communities of Poland. PWN-Polish Scientific Publishers, Warsaw. [In Polish].

32. Mirek Z., Piękoś-Mirkowa H., Zając A., Zając M. 2002. Flowering plants and pteridophytes of Poland - a checklist. In: Biodiversity of Poland 1. Mirek, Z. (Ed.), Szafer W. Institute of Botany, Polish Adacemy of Sciences, Kraków.

33. Pawluśkiewicz B., Janicka M., Piekut K. 2019. Effect of different introduction methods on plant species establishment success in wet grassland restoration. Polish J. of Environ. Stud., 28(3), 1857-1867.

34. Schäfer D., Klaus V.H., Kleinebecker T., Boeddinghaus R.S., Hinderling J., Kandeler E., Marhan S., Nowak S., Sonnemann I. Wurst S., Fischer M., Hölzel N., Hamer U., Prati D. 2019. Recovery of ecosystem functions after experimental disturbance in 73 grasslands differing in land-use intensity, plant species richness and community composition. J. Ecol., 00, 1-15, https://doi.org/10.1111/1365-2745.13211

35. Scotton M., Kirmer A., Krautzer B. (Eds.) 2012. Practical handbook for seed harvest and ecological restoration of species-rich grasslands. CLEUP, Padova, Italy.

36. Thompson K., Bakker J.P., Bekker R.M. 1997. The soil seedbanks of North West Europe: methodology, density and longevity. Cambridge University Press.

37. Török P., Janisová M., Kuzemko A., Rusina S., Dajic-Stevanovic Z. 2018. Grasslands, their threats and management in Eastern Europe. In: Squires, V.R., Dengler, J., Feng, H., Hua, L. (Eds.) Grasslands of the world: diversity, management and conservation. CRC Press, Boca Raton, USA, 64-88.

38. Török, P., Vida, E., Deák, B., Lengyel, S., Tóthmérész, B. 2011. Grassland restoration on former croplands in Europe: an assessment of applicability of techniques and costs. Biodiv. and Cons., 20(11), 2311-2332.

39. Wallin L., Svensson B.M., Lönn M. 2009. Artificial dispersal as a restoration tool in meadows: sowing or planting? Restoration Ecology, 17(2), 270-279.

40. Warda M., Kozłowski S. 2012. Grassland-a Polish resource, Proc. the $24^{\text {th }}$ General Meeting of the European Grassland Federation, Grassland Sci. Eur. 17, 3-16.

41. Wesche, K., Krause, B., Culmsee, H., Leuschner, C. 2012. Fifty years of change in Central European grassland vegetation: Large losses in species richness and animal pollinated plants. Biol. Cons. 150, 76-85. 